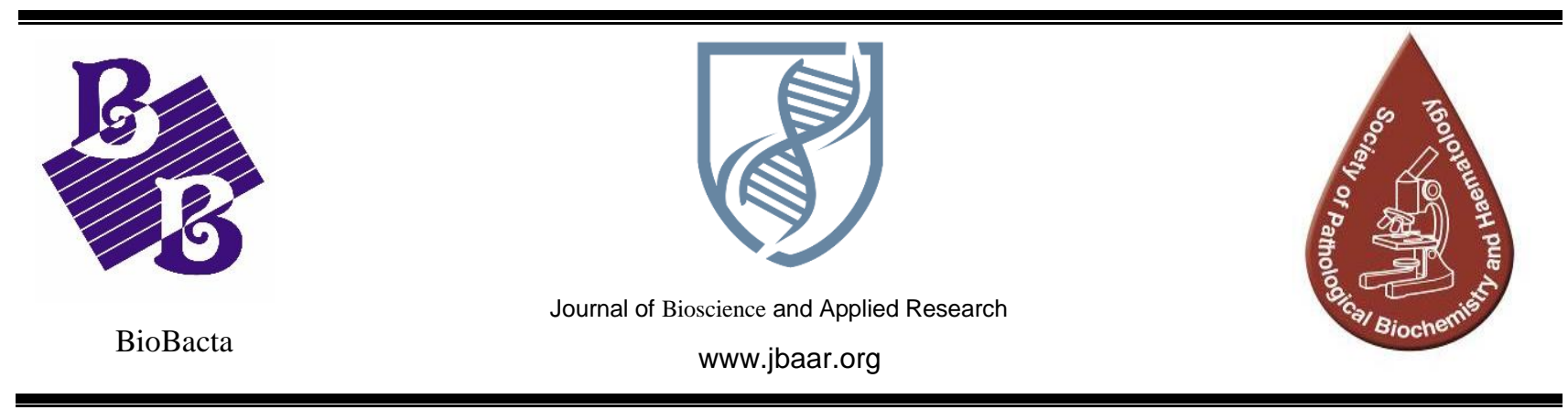

\title{
Assessment of cell-free DNA for early detection of ovarian cancer in women.
}

\section{Waleed M Fathy', Sabah Farouk², Gamalat Elgedawy ${ }^{3}$, Ayman Abd-Elhakim Abd-Elghany ${ }^{4}$, Amira Ahmed ${ }^{2}$}

\author{
${ }^{1}$ Clinical Pathology Department, Faculty of Medicine, Menufia University, Egypt \\ ${ }^{2}$ Molecular Biology Department, Genetic Engineering and Biotechnology Research Institute, Sadat City University Egypt \\ ${ }^{3}$ Biochemistry Department, National Liver Institute, Menufia University, Egypt \\ ${ }^{4}$ Obstetrics and Gynecology Department, General Organization of Teaching Hospital, Egypt.
}

Received date: January 15, 2019. Accepted: March 21, 2019, Published: March 28, 2019

\section{Abstract:}

DOI : 10.21608/jbaar.2019.138334

Objectives: To assess circulating cell-free DNA's diagnostic potential in Egyptian women with ovarian cancer. Background: Ovarian cancer (OC), one of the most common cancers worldwide, is the most lethal form of gynecological cancer, but the early detection of ovarian cancer would significantly decrease its mortality rate. Circulating plasma cell-free DNA (cfDNA) is nucleic acids in peripheral blood that originate from cell death caused by injury, apoptosis, and necrosis. Circulating cfDNA is normally found in small amounts in the blood of healthy individuals, although increased cfDNA levels have been reported in patients with various clinical conditions, including infection, inflammation, malignancy, connective tissue diseases, ischemic stroke, myocardial infarction, pregnancy-associated disorders, and hemodialysis. Subjects and Methods: This study was conducted on 50 patients with OC, 25 patients with benign ovary disease (BOD), and 25 healthy women used as a control group. All participants were tested for AFP, HCG, CA125, LDH, and circulating cfDNA, which were measured using real-time quantitative Polymerase chain reaction (RT-qPCR). Results: Circulation cfDNA rises more dramatically between OC cases than in both BOD cases and healthy controls, and the results indicate that circulating cfDNA was significantly higher in the OC group $(\mathrm{p}<0.001)$ than both the BOD and control groups. The receiver operator of characteristics (ROC) curve analysis of circulating cfDNA revealed that at a cut-off value of $>4.13$ (fold expression), the sensitivity and specificity for differentiation of OC cases from non-cancer subjects were $97.3 \%$ and $92 \%$, respectively. A significant positive correlation was found between circulating cfDNA and CA 125.Conclusion: Circulating CfDNA might be a biomarker for the early diagnosis of ovarian cancer.

Keywords: Circulating cfDNA, Ovarian cancer, Polymerase chain reaction (RT-qPCR) 


\section{Introduction:}

Cancer continues to represent a huge economic and social burden to society. Ovarian cancer (OC) accounts for an estimated 239,000 new cases and 152,000 deaths worldwide annually [1]. Ovarian cancer is the sixth most common cancer, it is the second most common and lethal gynecologic malignancy., In 2014, over 220,000 diagnoses of epithelial ovarian cancer were made yearly [2].The 5 - year survival rate for stage I ovarian cancer is over $80 \%$, compared with a survival rate of only $11 \%$ for stage IV ovarian cancer [3]

Ovarian cancer is the fourth most common cancer among Egyptian women, Ovarian cancer accounts for $2.5 \%$ of all malignancies among females but $5 \%$ of female cancer deaths because of low survival rates, largely driven by late-stage diagnosis [4]. In Egypt, the incidence rate of ovarian cancer during the period from 2008 to 2011 was reported to be 5.3 per 100,000 populations [5].

In Egypt, Ibrahim et al showed that ovarian cancer represented $2.2 \%$ of all incident cancers and accounted for $4.4 \%$ of all newly diagnosed female cancers. [6]. Another important regional registry in Egypt is the Aswan regional registry, in which thirty-five cases of ovarian cancer were registered in 2008, representing $5.6 \%$ of all female cancer cases (7).

CA-125 is a Food and Drug Administration (FDA)-approved biomarker used for monitoring ovarian cancer, levels can rise non-specifically in patients with non-cancerous conditions and stay within a normal range in the presence of persistent disease, making CA-125 inadequate for screening and surveillance [8]. The biopsy is the method used to establish a definitive diagnosis, but it's thought that if ovarian cancer is present, this could result in what's known as seeding but it is an invasive procedure [9].

This disadvantage of screening methods requires a biomarker that can detect $\mathrm{OC}$ at an early stage. The use of Circulating cell-free DNA as a biomarker in clinical medicine for early diagnosis, prognosis, and monitoring of therapy has been a significant advancement in the biomedical field (10).
Circulating plasma cell-free DNA (cfDNA) is nucleic acids in peripheral blood that originate from cell death caused by injury, apoptosis, and necrosis (11).

Circulating cell-free DNA can be released into the bloodstream either through cell death, i.e. apoptosis (yellow) or necrosis (green) or it can be released by viable cells (purple). Cell-free DNA can be present in the form of unbound DNA, nucleosomes, vesicle-bound DNA, or virtosomes. CfDNA is normally found in small amounts in the blood of healthy individuals, although increased cfDNA levels have been reported in patients with various clinical conditions including infection, inflammation, malignancy, connective tissue diseases, ischemic stroke, myocardial infarction, pregnancy-associated disorders, and hemodialysis (HD) (12).

The use of DNA assay can be significantly sensitive and specific if cancer-specific DNA alterations are tested instead of elevation of circulating DNA concentration. Whether the DNA is present in normal locations such as the nucleus and mitochondria or circulating free in the blood and body fluids (10).

\section{Aim of Work:}

This study was proceeded to assess the diagnostic potential value of circulating cell-free DNA expression patterns in Egyptian women with ovarian cancer in comparison to healthy controls.

\section{Materials and methods:}

The present study was carried out at the Clinical Pathology Department, faculty of medicine, Biochemistry Department, National liver Institute, Menoufiya University, in the duration between October 2016 to October 2018. The patients were selected from the Out-patient Clinics of surgery in El-Menoufia University Hospitals.

The present study was conducted on 100 subjects; including 50 female patients with ovarian cancer (OC), their ages ranged from 30 to 63 years, and 25 female patients with the benign ovarian disease (BOD), their ages ranged from 26 to 60 years. Also, 25 unrelated healthy females matching age served as a control group and their ages ranged from 20 to 60years. The diagnosis of OC was based on clinical 
examination, laboratory diagnosis, a transvaginal ultrasound, pelvic examination. Also, the diagnosis of BOD was based on clinical examination, laboratory tests, and transvaginal ultrasound, pelvic examination.

Exclusion criteria: Subjects who fulfilled one of the following criteria were excluded:

Autoimmune diseases, Acute or severe chronic liver disease, Acute inflammatory diseases, Hematologic diseases, Malignancy, Connective tissue diseases, Ischemic stroke, Myocardial infarction, Pregnancy.

The study was approved by the ethics committee of Genetic Engineering and Biotechnology Research Institute, EL-Sadat University, and Faculty of Medicine, Menoufia University. Enrolment of individuals in the study was conditioned by an obtained written informed consent. All patients and control groups were subjected to full history taking, complete clinical examination, mammography, and laboratory investigation.

\section{Laboratory investigations:}

Ten $\mathrm{ml}$ of venous blood were collected from all subjects included the First part in a plain vacutainer tube left to clot at $37^{\circ} \mathrm{C}$. Sera were separated by centrifugation and used for immediate assay of the liver (AST, ALT ), kidney functions ( Urea, Creatinine )\&tumor markers ( CA 125, $\beta \mathrm{HCG}$, AFP, and LDH ). The second part was collected on a dipotassium ethylenediamine tetra-acetic acid (EDTA) tube for CBC. The third part was transferred into another (EDTA) tube and then centrifuged for 10 minutes at 4000 r.p.m. The plasma was transferred to new Eppendorf tubes and centrifuged again at maximum speed $(16,000 \mathrm{~g})$ for 10 minutes to remove cellular DNA completely from the plasma fractions. Then DNA was extracted for estimation of cell-free DNA \& kept at $-20 \mathrm{C}$ until the time of analysis.

The following laboratory investigations were done: liver function tests including ALT, AST, Creatinine, Urea, and LDH were done by using Synchron Cx 9 ALX Clinical Autoanalyzer from Beckman Coulter, USA.
Serum CA $125, \beta H C G, \&$ AFP were done by mini VIDAS systems (bioMérieux, Marcy l'Etoile, France) which is an automated enzyme-linked fluorescent immunoassay (ELFA) based on a onestep immunoassay sandwich method and a final fluorescent detection step for the quantitative measurements.

\section{Molecular testing:}

Relative quantification of CCFDNA levels using real-time PCR amplification of target DNA using specific complementary primers (beta-globin )and hybridization of the amplified products to fluorogenic probe using (7500 fast real-time PCR TaqMan DNA and Genomic DNA Control Assay) was performed through the following processes:

DNA extraction: CCFDNA were extracted from fresh EDTA treated blood sample using Macherey-Nagel $\mathrm{GmbH} \&$ Co. KG, Germany kit according to the manufacturer's instructions.

\section{Amplification:}

Determination of the $\beta$-globin gene in cfDNA levels was done by TaqMan DNA Assay using Universal TaqMan master mix (Applied Biosystems, Thermo Fisher Scientific) according to the manufacturer's protocol. Fluorescence measurements were made in every cycle and the cycling conditions used for amplification of $\beta$-globin gene in cfDNA were initial denaturation step at $95 \mathrm{LC}$ for $15 \mathrm{~min}$ followed by 40 cycles of $95 \mathrm{LC}$ for $15 \mathrm{~s}$ and 40 cycles of $60 \mathrm{LC}$ for $60 \mathrm{~s}$.

\section{Quantification:}

Quantification of total plasma DNA was performed using real-time PCR with TaqMan Assay with primers directed to beta-globin. Primer sequences used were: forward 5'- GTG CAC CTG ACT CCT GAG GAG A -3'; reverse 5'- CCT TGA TAC CAA CCT GCC CAG -3'; probe 5'-AAG GTG AAC GTG GAT GAA GTT GGT GG -3'.

A standard curve was created with serial dilution $(139,13.9,1.39,0.139,0.0139)$ and DNA concentration, expressed as genome equivalents $/ \mathrm{ml}$ ( $\mathrm{GE} / \mathrm{ml}$ ), was calculated using the following equation $\mathrm{C}=\mathrm{Q} \times(\mathrm{VDNA} / \mathrm{VPCR}) \times(1 / \mathrm{Vext})$ 
$\mathrm{C}$ is target concentration in plasma $(\mathrm{GE} / \mathrm{ml}), \mathrm{Q}$ is target quantity (copies), VDNA is the total volume of DNA extraction $(50 \mu \mathrm{L}), \mathrm{VPCR}$ is a volume of DNA used per PCR reaction ( $5 \mu \mathrm{L})$, and Vext is a volume of plasma used to extract DNA $(240 \mu \mathrm{L})$.

\section{Statistical analysis:}

Data were collected and analyzed using IBM SPSS software package version 20.0.

The following tests; sensitivity, specificity, significance of results (P-value), ANOVA, Kruskal Wallis test, and Spearman correlation test were calculated to compare mean RQs of CCFDNA between OC, BOD, and control groups in Egyptian women patients.

Spearman's rank correlation coefficient was used to examine the correlation between the level of CCFDNA

\section{Result}

Table (1): This shows that AST, ALT, Creatinine, and Urea were significantly higher in group I (OC) than both groups II (BOD) and III (Control) $(p<0.001)$.

Table (1): Comparison between the three studied groups according to liver function and kidney function

\begin{tabular}{|c|c|c|c|c|c|}
\hline & $\begin{array}{l}\text { Group I } \\
(\mathbf{n}=\mathbf{5 0})\end{array}$ & $\begin{array}{c}\text { Group II } \\
(\mathbf{n}=25)\end{array}$ & $\begin{array}{c}\text { Group III } \\
(\mathbf{n}=\mathbf{2 5})\end{array}$ & $\begin{array}{l}\text { Test of } \\
\text { sig. }\end{array}$ & $\mathbf{p}$ \\
\hline \multicolumn{6}{|l|}{ AST U/l } \\
\hline Min. - Max. & $22.0-86.0$ & $22.0-45.0$ & $22.0-37.0$ & \multirow{3}{*}{$\begin{array}{c}\mathrm{H}= \\
34.368^{*}\end{array}$} & \multirow{3}{*}{$<0.001^{*}$} \\
\hline Mean \pm SD & $41.70 \pm 12.87$ & $32.16 \pm 6.49$ & $27.44 \pm 4.10$ & & \\
\hline Median & 39.0 & 31.0 & 28.0 & & \\
\hline Sig. bet. Groups & \multicolumn{3}{|c|}{$\mathrm{p}_{1}=0.001^{*}, \mathrm{p}_{2}<0.001^{*}, \mathrm{p}_{3}=0.029^{*}$} & & \\
\hline ALT $\quad \mathbf{U} / \mathbf{l}$ & & & & \multirow{4}{*}{$\begin{array}{c}\mathrm{F}= \\
23.307^{*}\end{array}$} & \multirow{4}{*}{$<0.001^{*}$} \\
\hline Min. - Max. & $26.0-67.0$ & $22.0-44.0$ & $21.0-39.0$ & & \\
\hline Mean \pm SD & $41.24 \pm 10.76$ & $31.92 \pm 6.07$ & $28.0 \pm 4.39$ & & \\
\hline Median & 40.50 & 32.0 & 27.0 & & \\
\hline Sig. bet. Groups & \multicolumn{3}{|c|}{$\mathrm{p}_{1}<0.001^{*}, \mathrm{p}_{2}<0.001^{*}, \mathrm{p}_{3}=0.238$} & & \\
\hline \multicolumn{6}{|l|}{ Urea mg/dl } \\
\hline Min. - Max. & $28.0-45.0$ & $27.0-39.0$ & $26.0-33.0$ & \multirow{3}{*}{$\begin{array}{c}\mathrm{F}= \\
28.379^{*}\end{array}$} & \multirow{3}{*}{$<0.001^{*}$} \\
\hline Mean \pm SD & $34.80 \pm 3.57$ & $31.36 \pm 2.98$ & $29.44 \pm 1.66$ & & \\
\hline Median & 34.50 & 31.0 & 29.0 & & \\
\hline Sig. bet. Groups & \multicolumn{3}{|c|}{$\mathrm{p}_{1}<0.001^{*}, \mathrm{p}_{2}<0.001^{*}, \mathrm{p}_{3}=0.073$} & & \\
\hline Creatinin mg/dl & & & & \multirow{4}{*}{$\begin{array}{c}\mathrm{F}= \\
24.719^{*}\end{array}$} & \multirow{4}{*}{$<0.001^{*}$} \\
\hline Min. - Max. & $0.90-1.24$ & $0.85-1.25$ & $0.75-1.05$ & & \\
\hline Mean \pm SD & $1.06 \pm 0.11$ & $1.0 \pm 0.10$ & $0.89 \pm 0.09$ & & \\
\hline Median & 1.06 & 1.0 & 0.90 & & \\
\hline Sig. bet. Groups & \multicolumn{3}{|c|}{$\mathrm{p}_{1}=0.032^{*}, \mathrm{p}_{2}<0.001^{*}, \mathrm{p}_{3}=0.001^{*}$} & & \\
\hline
\end{tabular}

$\mathrm{X}=$ mean, $\mathrm{SD}=$ standard deviation, $\mathrm{P}$-value of $<0.001^{*}$ was considered statistically highly significant, $\mathrm{P}$-value of $<0.05^{*}$ was considered statistically significant and P-value of $>0.05$ was considered statistically non-significant.

$\mathrm{p}_{1}$ : $\mathrm{p}$-value for comparing between group $\mathrm{I}(\mathrm{OC})$ and group II(BOD)

p2: p-value for comparing between group I (OC)and group III(Control)

$\mathrm{p}_{3}$ : p-value for comparing between-group II (BOD)and group III(Control) 
Table (2): shows that CA125, LDH, and AFP were significantly higher in group I (OC) than both groups II (BOD) and III (Control) $(\mathrm{p}<0.001)$

Table (2)Comparison between the three studied groups according to Ca125, LDH, AFP, and $\beta$-HCG

\begin{tabular}{|c|c|c|c|c|c|}
\hline & $\begin{array}{l}\text { Group I } \\
(\mathbf{n}=\mathbf{5 0})\end{array}$ & $\begin{array}{c}\text { Group II } \\
(\mathbf{n}=\mathbf{2 5})\end{array}$ & $\begin{array}{c}\text { Group III } \\
(\mathbf{n}=\mathbf{2 5})\end{array}$ & $\mathbf{H}$ & $\mathbf{p}$ \\
\hline CA125 U/ml & & & & & \\
\hline Min. - Max. & $8.90-780.0$ & $5.80-534.0$ & $1.33-18.90$ & & \\
\hline Mean \pm SD & $186.7 \pm 215.1$ & $70.11 \pm 141.6$ & $5.67 \pm 3.76$ & $59.940^{*}$ & $<0.001^{*}$ \\
\hline Median & 80.70 & 15.50 & 4.90 & & \\
\hline Sig. bet. Groups & \multicolumn{3}{|c|}{$\mathrm{p}_{1}=0.002^{*}, \mathrm{p}_{2}<0.001^{*}, \mathrm{p}_{3}<0.001^{*}$} & & \\
\hline LDH U/L & & & & \multirow{4}{*}{$26.400^{*}$} & \multirow{4}{*}{$<0.001^{*}$} \\
\hline Min. - Max. & $227.0-422.0$ & $244.0-412.0$ & $211.0-835.0$ & & \\
\hline Mean \pm SD & $346.8 \pm 53.31$ & $318.0 \pm 44.49$ & $289.0 \pm 121.6$ & & \\
\hline Median & 355.5 & 314.0 & 265.0 & & \\
\hline Sig. bet. Groups & \multicolumn{3}{|c|}{$\mathrm{p}_{1}=0.046^{*}, \mathrm{p}_{2}<0.001^{*}, \mathrm{p}_{3}=0.007^{*}$} & & \\
\hline AFP $\quad \mathrm{ng} / \mathrm{ml}$ & & & & \multirow{5}{*}{$39.692^{*}$} & \multirow{4}{*}{$<0.001^{*}$} \\
\hline Min. - Max. & $0.76-22.30$ & $0.99-7.80$ & $0.55-3.50$ & & \\
\hline Mean \pm SD & $5.71 \pm 4.06$ & $4.27 \pm 1.78$ & $1.73 \pm 0.84$ & & \\
\hline Median & 5.10 & 3.90 & 1.80 & & \\
\hline Sig. bet. Groups & \multicolumn{3}{|c|}{$\mathrm{p}_{1}=0.268^{*}, \mathrm{p}_{2}<0.001^{*}, \mathrm{p}_{3}<0.001^{*}$} & & \\
\hline $\begin{array}{l}\boldsymbol{\beta} \text {-HCG mlu/ml } \\
\text { Min. - Max. }\end{array}$ & $1.22-5.17$ & $1.90-4.70$ & $1.88-4.90$ & \multirow{3}{*}{0.453} & \multirow{3}{*}{0.637} \\
\hline Mean \pm SD & $3.22 \pm 0.98$ & $3.27 \pm 0.83$ & $3.44 \pm 0.87$ & & \\
\hline Median & 3.11 & 3.20 & 3.60 & & \\
\hline
\end{tabular}

$\mathrm{X}=$ mean, $\mathrm{SD}=$ standard deviation, $\mathrm{P}$-value of $<0.001^{*}$ was considered statistically highly significant, $\mathrm{P}$-value of $<0.05^{*}$ was considered statistically significant and P-value of $>0.05$ was considered statistically non-significant.

$\mathrm{p}_{1}$ : p-value for comparing between group I (OC)and group II(BOD)

$\mathrm{p}_{2}$ : p-value for comparing between group I (OC)and group III(Control)

$\mathrm{p}_{3}$ : p-value for comparing between-group II (BOD)and group III(Control) 
Table (3) shows that CCFDNA was significantly higher in group I (OC) than both groups II (BOD) and III (Control) $(\mathrm{p}<0.001)$

Table (3): Comparison between the three studied groups according to CCFDNA of ovarian

\begin{tabular}{|c|c|c|c|c|c||}
\hline $\begin{array}{c}\text { CCFDNA of } \\
\text { ovarian }\end{array}$ & $\begin{array}{c}\text { Group 1 } \\
(\mathbf{n = 5 0})\end{array}$ & $\begin{array}{c}\text { Group 2 } \\
(\mathbf{n = 2 5})\end{array}$ & $\begin{array}{c}\text { Group 3 } \\
(\mathbf{n = 2 5})\end{array}$ & H & p \\
\hline Min. - Max. & $0.54-24.75$ & $0.11-6.48$ & $0.02-1.71$ & & \\
Mean \pm SD. & $11.32 \pm 6.49$ & $1.52 \pm 1.68$ & $0.26 \pm 0.49$ & $76.114^{*}$ & $<0.001^{*}$ \\
Median & 9.49 & 0.96 & 0.08 & & \\
\hline Sig. bet. Groups & \multicolumn{2}{|c|}{$\mathrm{p}_{1}<0.001^{*}, \mathrm{p}_{2}<0.001^{*}, \mathrm{p}_{3}=0.008 \mathrm{P}^{*}$} & & \\
\hline
\end{tabular}

$\mathrm{X}=$ mean, $\mathrm{SD}=$ standard deviation, $\mathrm{P}$-value of $<0.001 *$ was considered statistically highly significant, $\mathrm{P}$-value of $<0.05^{*}$ was considered statistically significant and P-value of $>0.05$ was considered statistically non-significant. $\mathrm{p}_{1}$ : $\mathrm{p}$-value for comparing between group I (OC)and group II(BOD)

$\mathrm{p}_{2}$ : p-value for comparing between group I (OC)and group III(Control)

p3: p-value for comparing between-group II (BOD)and group III(Control)

Table (4) shows that there is a statistically significant correlation between CT and CA125, ALT and Urea in total cases.

Table (4) Correlation between different parameters in each group

\begin{tabular}{|c|c|c|c|c|c|c|}
\hline & \multicolumn{6}{|c|}{ CT of ovarian } \\
\hline & \multicolumn{2}{|c|}{$\begin{array}{l}\text { Total cases } \\
\quad(n=75)\end{array}$} & \multicolumn{2}{|c|}{$\begin{array}{c}\text { Group I } \\
(\mathbf{n}=\mathbf{5 0})\end{array}$} & \multicolumn{2}{|c|}{$\begin{array}{c}\text { Group II } \\
(\mathbf{n}=\mathbf{2 5})\end{array}$} \\
\hline & $\mathbf{r}_{\mathrm{s}}$ & $\mathbf{p}$ & $\mathbf{r}_{\mathrm{s}}$ & $\mathbf{p}$ & $\mathbf{r}_{\mathrm{s}}$ & $\mathbf{p}$ \\
\hline Age (years) & 0.189 & 0.104 & 0.184 & 0.202 & 0.047 & 0.824 \\
\hline AST & 0.226 & 0.051 & -0.129 & 0.372 & 0.175 & 0.403 \\
\hline ALT & 0.291 & $0.011^{*}$ & -0.059 & 0.683 & 0.003 & 0.988 \\
\hline Urea & 0.532 & $<0.001^{*}$ & 0.342 & $0.015^{*}$ & 0.036 & 0.864 \\
\hline Creatinin & 0.159 & 0.174 & -0.185 & 0.199 & 0.090 & 0.668 \\
\hline HB & -0.036 & 0.757 & -0.007 & 0.964 & -0.131 & 0.534 \\
\hline RBCs & -0.011 & 0.925 & -0.066 & 0.647 & -0.097 & 0.644 \\
\hline WBCs & 0.128 & 0.274 & 0.005 & 0.975 & 0.251 & 0.227 \\
\hline PLT & 0.194 & 0.095 & 0.020 & 0.890 & 0.246 & 0.235 \\
\hline CA125 & 0.313 & $0.006^{*}$ & 0.011 & 0.941 & 0.065 & 0.757 \\
\hline LDH & 0.017 & 0.885 & 0.051 & 0.727 & 0.361 & 0.076 \\
\hline AFP & 0.112 & 0.340 & 0.254 & 0.075 & 0.051 & 0.810 \\
\hline$\beta$-HCG & 0.166 & 0.156 & 0.015 & 0.916 & 0.065 & 0.756 \\
\hline
\end{tabular}


Table (5) shows the validity of CCFDNA of ovarian for prediction of diagnosis cases versus control with Cutoff point 0.14 , Sensitivity $97.33 \%$, and Specificity $88.0 \%$.

Table (5)Agreement (sensitivity, specificity) for CCFDNA of ovarian to diagnosis cases versus control

\begin{tabular}{|c|c|c|c|c|c|}
\hline & 节 & 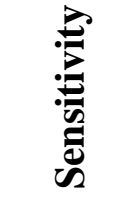 & 苞 & $\vec{a}$ & $\vec{z}$ \\
\hline CCFDNA of ovarian & $>0.14$ & 97.33 & 88.0 & 96.1 & 91.7 \\
\hline
\end{tabular}

AUC: Area Under a Curve

P-value: Probability value

CI: Confidence Intervals

Table (6) shows the validity of CCFDNA of ovarian for prediction diagnosis cases versus benign with Cutoff point 4.13 , Sensitivity $92.0 \%$, and Specificity $92.0 \%$

Table (6)Agreement (sensitivity, specificity) for CCFDNA of ovarian to diagnosis cancer cases versus benign

\begin{tabular}{|c|c|c|c|c|c|}
\hline & 苞 & 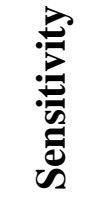 & 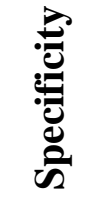 & $\frac{a}{a}$ & $\vec{z}$ \\
\hline CCFDNA of ovarian & $>4.13$ & 92.0 & 92.0 & 95.8 & 85.2 \\
\hline
\end{tabular}

AUC: Area Under a Curve

P-value: Probability value

CI: Confidence Intervals

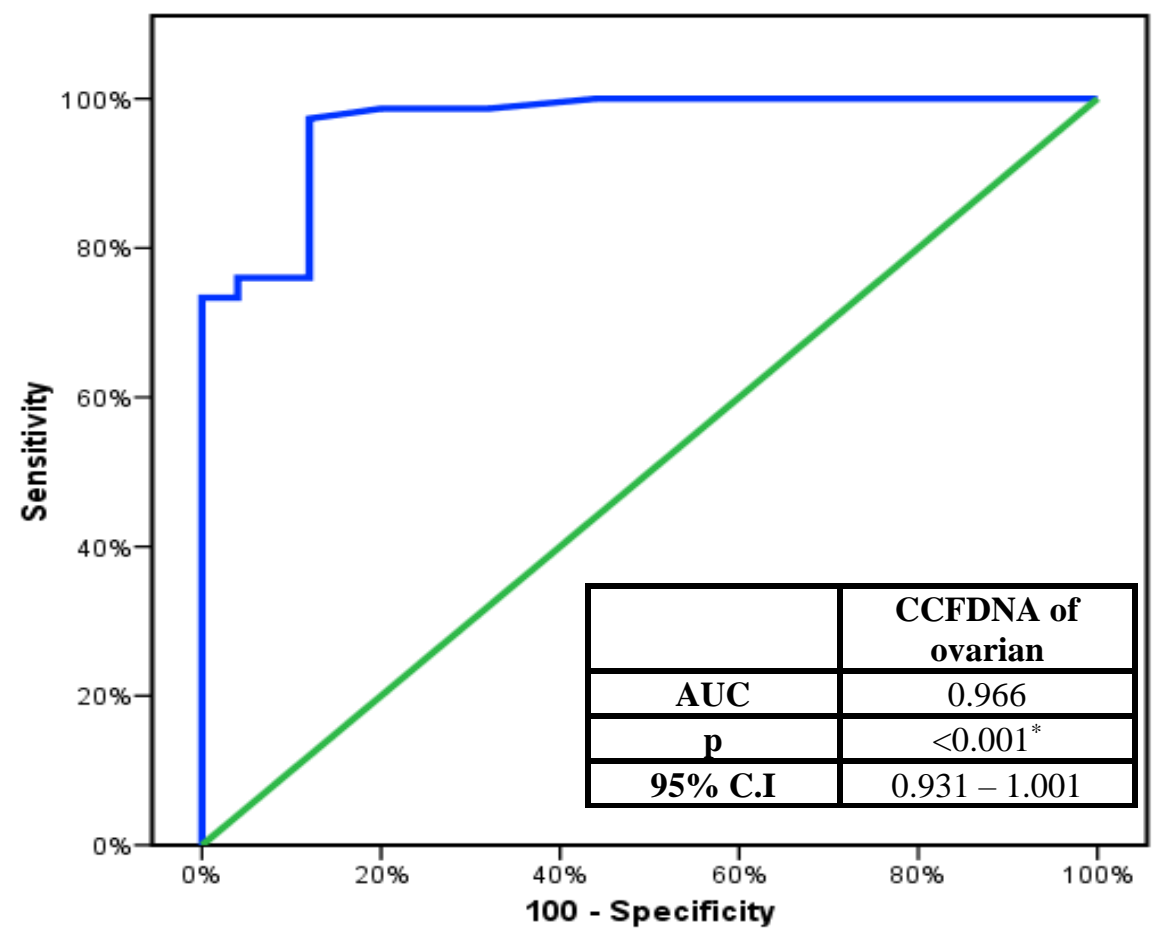

Figure (1): ROC curve for CCFDNA of ovarian to diagnosis cases versus control 


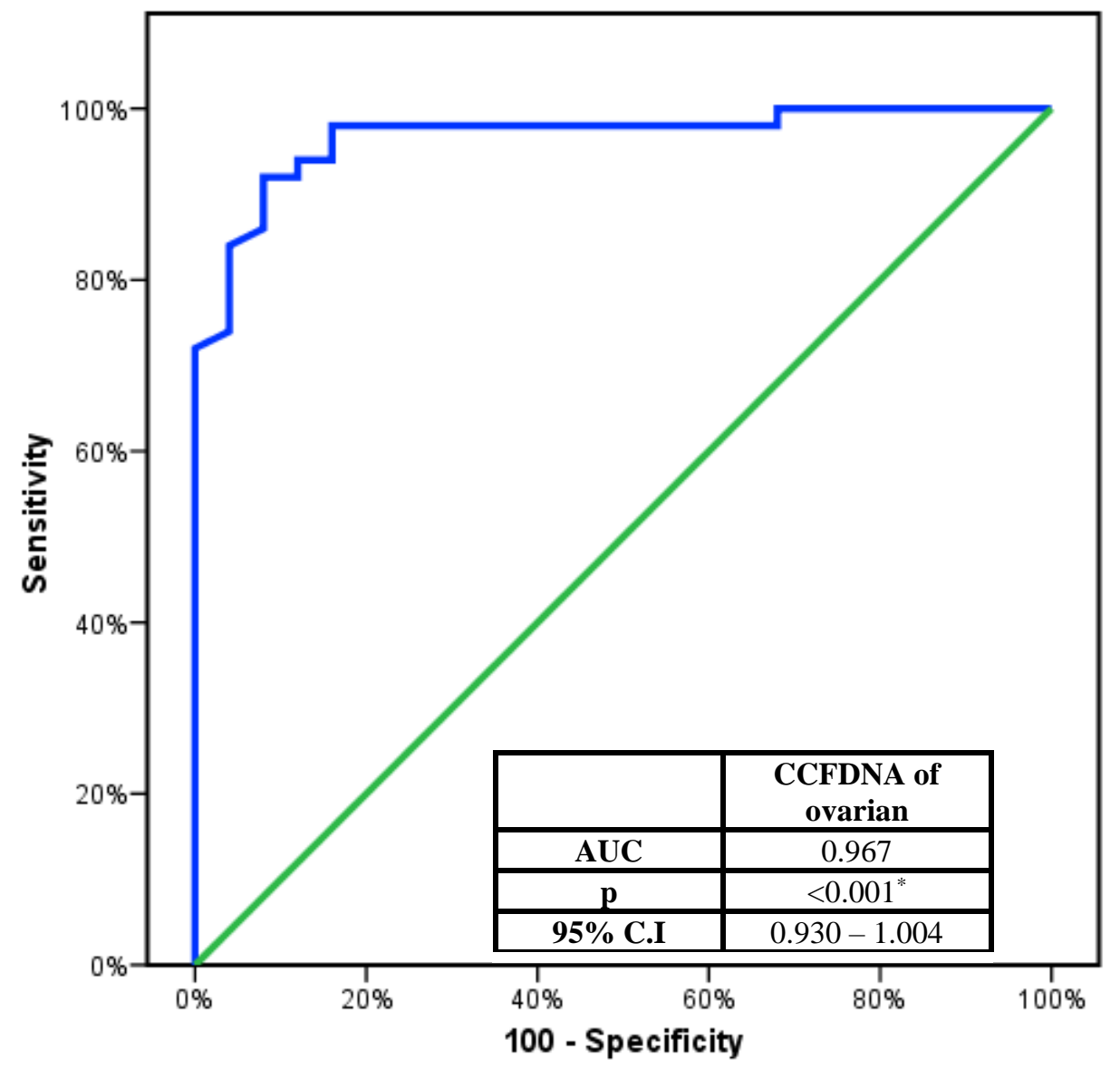

Figure (2): ROC curve for CCFDNA of ovarian to diagnosis cancer cases versus benign

\section{Discussion:}

In Egypt, among females, high frequency of breast cancer (52.4) followed by liver (16.7), non-Hodgkin lymphoma (10.8), Colorectum (6.3), ovary (6.1) [13], efficient diagnostic tools for early detection are keys to survival, Because the stage of the disease at diagnosis is associated with prognosis.

Serum tumor markers such as CA125 has a high sensitivity, but it is also frequently elevated in benign gynecologic disorders, such as endometriosis, fibroids, and pelvic inflammatory disease [14], and not every patient with cancer will have elevated levels of CA-125 in their blood. (Ferrini R, 1997) [15],CA-125 has particularly poor sensitivity that means the use of CA-125 to detect ovarian cancer (especially in the early stages of disease) can frequently lead to false negatives. Patients that receive false negatives are unlikely to seek further treatment for their disease. Consequently, there is an urgent need for diagnostically sensitive, specific, and non-invasive markers for early breast cancer detection.

CCFDNA could emerge as biomarkers for the diagnosis and prognosis of different diseases, including ovarian cancer. Circulating plasma cell-free DNA (cfDNA) is nucleic acids in peripheral blood that originate from cell death caused by injury, apoptosis, and necrosis [11]

CCFDNA in the circulation system might function as feasible biomarkers in early-stage ovarian cancer detection, the DNA is present in normal locations such as the nucleus and mitochondria or circulating free in the blood and body fluids, it can be utilized as a valuable biomarker. Circulating DNA as a biomarker is easily accessible, reliable, and reproducible. Also, the use of DNA assays for clinical medicine can be significantly sensitive and specific if cancer-specific DNA alterations are tested instead of elevation of circulating DNA concentration [10]. 
Preoperative DNA levels are significantly elevated in patients with ovarian carcinoma when compared to individuals with benign ovarian disease and controls. DNA levels were elevated even among patients with early-stage ovarian cancer [16].

Many studies demonstrated that tumor progression was significantly correlated with increasing plasma DNA concentrations in patients with ovarian cancer.

Gautschi and colleagues found that tumor progression was significantly correlated with increasing plasma DNA concentrations in patients with non-small cell lung cancer [17]. Wei and colleagues performed quantitative analysis of Epstein-Barr virus (EBV) DNA in the plasma of nasopharyngeal carcinoma (NPC) patients and found that surgical resection of the tumor was associated with a significant decrease in the EBV DNA copy numbers [18]. Another group has reported that significantly elevated pre-therapy plasma EBV DNA levels are a powerful predictor of clinical outcome in patients with early-stage NPC [19].

CFDNA levels correlate with clinical stage, lymph node metastasis, and tumor size in breast cancer [20]. A study performed a quantitative comparison of matched serum and plasma DNA in patients with colorectal liver metastasis and found that only plasma DNA was predictive of recurrence. These authors concluded that plasma DNA better reflects the in vivo levels of circulating DNA [21]. Using an orthotopic mouse model of ovarian cancer to detect tumor-derived CFDNA, we showed that CFDNA closely correlates with tumor load and levels decline appreciably with chemotherapy [22]. Zachariah and colleagues have reported elevated levels of both cell-free nuclear and mitochondrial DNA among ovarian cancer patients compared to controls, but levels of cell-free DNA did not correlate with prognosis in their cohort (14)

This work demonstrated that CCFDNA is upregulated in $\mathrm{OC}$ where mean circulating free DNA potential value in patients with $\mathrm{OC}$ was significantly higher compared to patients with BOD and healthy individuals, this was in agreement with Aperna et al[15], who reported that CCFDNA was elevated in early-stage OC blood samples compared with healthy controls.

In the current study, it is also observed that there is a significant increase of the mean potential value of CCFDNA with the progress of OC as it showed a significant increase with advanced tumor stage, which might indicate that circulating cell-free DNA resulted from tumor secretion and that CCFDNA could be a potential prognostic marker in $\mathrm{OC}$, in the present study, we have shown that CFDNA $\geq 22,000 \mathrm{GE} / \mathrm{ml}$ is a powerful independent predictor of poor outcome in patients with ovarian carcinoma. Also, on applying this cutoff to a separate validation set, CFDNA levels maintain their statistical significance. Interestingly, the combination of CA125 and CFDNA levels did not improve the likelihood of predicting mortality over CFDNA levels alone.

We also attempted to characterize the utility of preoperative CFDNA levels for detecting malignancy. The sensitivity and specificity for detecting ovarian cancer using CFDNA cut-off at 4,13 $\mathrm{GE} / \mathrm{ml}$ were $92-92 \%$.

In the present study, although levels of CFDNA were significantly higher among patients with early-stage disease, detection of total or tumor-specific CFDNA holds promise as a diagnostic test for women with ovarian cancer, alone or in combination with available modalities such as CA125 levels and transvaginal ultrasound. Chang and colleagues provided some of the early evidence for the use of allelic imbalance (AI) to detect patients with ovarian cancer [23]. They reported that the area under the ROC curve using AI in plasma DNA was 0.95 .

Hypermethylation of the normally unmethylated BRCA1 and RAS association domain family protein 1a tumor suppressor genes was detected in the serum of patients with ovarian cancer with $82 \%$ sensitivity [24]. In contrast, these authors report no hypermethylation in non-neoplastic tissue, peritoneal fluid, or serum from 40 control women $(100 \%$ specificity) [24].

In summary, results from this study add to the mounting evidence that levels of plasma CFDNA are 
significantly elevated in patients with ovarian cancer compared to those with benign ovarian disease and controls.

\section{Conclusions:}

This study approves the diagnostic and prognostic potential value of CCFDNA in ovarian cancer. It could be used as a non-invasive diagnostic biomarker for the early detection of OC in Egyptian women as CCFDNA showed higher sensitivity and specificity than other markers such as CA125. Also, CCFDNA could be a good prognostic biomarker for ovarian cancer as it showed a progressive increase with the grade and stage of the tumor.

\section{References:}

1. Ferlay J, Soerjomataram I, Dikshit R. et al.(2015): Cancer incidence and mortality worldwide: sources, methods and major patterns in GLOBOCAN 2012. Int J Cancer. 136:E359-386

2. Jayson GC, Kohn EC, Kitchener HC, Ledermann JA (2014): Ovarian cancer .Lancet. 384 (9951): 1376-88

3. Fast Stats (2016): An interactive tool for access to SEER cancer statistics, Surveill. Res. Program, NCIhscgf, Elsevier Inc;0090-8258

4. Howlader N, Noone AM, Krapcho M, et al.(2017): eds. SEER Cancer Statistics Review, 1975-2014. Bethesda, MD: National Cancer Institute; 2017. . CA CANCER J CLIN;68:284-296

5. Ibrahim A, Khaled $\mathbf{H}$, Mikhail $\mathbf{N}$, et al. (2014): Cancer Incidence in Egypt: Results of the National Population-Based Cancer Registry Program. Journal of Cancer Epidemiology:1-18

6. Ibrahim AS, Seif-Eldin IA, Ismail K, Hablas A, Hussein H, Elhamzawy H.(2007): Cancer in Egypt, Gharbiah: Triennial Report of 2000-2002, Gharbiah

Population-based Cancer Registry. Cairo: Middle East Cancer Consortium. Int J Reprod Contracept Obstet Gynecol. ;7(11):4575-4580

7. Ibrahim AS, Mihhail NN. Egypt National Cancer Registry(2008 ): Aswan Profile:
Ministry of Communication and InformationTechnology:2008.73-75

8. S.S.Ricci(2013): screening for ovarian cancer :AReality Check , Curr . obstet .Gymecol.Rep.2;74-75

9. Kerlikowske K, Zhu W, Hubbard RA, et al (2013): Breast Cancer Surveillance Consortium. Outcomes of screening mammography by frequency, breast density, and postmenopausal hormone therapy. JAMA Intern Med. 173(9):807-81

10. Jin D, Xie S, Mo Z, Liang Y, Guo B \& Yu M (2012): Circulating DNA-important biomarker of cancer. J. Mol. Biomarkers Diagn; 2: 009

11. Schwarzenbach H, Hoon DS \& Pantel K (2011): Cell-free nucleic acids as biomarkers in cancer patients. Nature Reviews Cancer; 11(6): 426-437

12. Yi J, Zhang Y, Zhang Y, Ma Y, Zhang C, Li $Q$ et al (2014): Increased plasma cell-free DNA level during HTNV infection: correlation with disease severity and virus load. Viruses; 6: 2723-2734.

13. World Health Organization. Global Health Observatory. Geneva: World Health Organization; 2018. who.int/gho/database/en/. Accessed June 21, 2018.

14. Tian C, Markman M, Zaino R, et al (2009 ): CA-125 change after chemotherapy in prediction of treatment outcome among advanced mucinous and clear cell epithelial ovarian cancers: a gynecologic oncology group study. Cancer.;115:1395-403.

15. Ferrini $R$ (1997): Screening asymptomatic women for ovarian cancer: American College of Preventive Medicine practice policy" (PDF). American Journal of Preventive Medicine. 13 (6): 444-6.

16. Kamat AA, Sood AK, Dang D, Gershenson DM, Simpon JL, Bischoff FZ et al (2011): Quantification of total plasma cell-free DNA in ovarian cancer using real-time PCR. Cancer; 116(8): 1918-1925 
17. Gautschi O, Bigosch C, Huegli B, et al(2004): Circulating deoxyribonucleic acid as a prognostic marker in non-small cell lung cancer patients undergoing chemotherapy. J Clin Oncol.;22:4157-64.

18. .Wei WI, Yuen AP, Ng RW, Kwong DL, Sham JS(2004): Quantitative analysis of plasma cell-free Epstein-Barr virus DNA in nasopharyngeal carcinoma after salvage nasopharyngectomy: a prospective study. Head Neck.;26:878-83

19. .Leung SF, Chan AT, Zee B, et al(2003): Pretherapy quantitative measurement of circulating Epstein-Barr virus DNA is predictive of posttherapy distant failure in patients with early-stage nasopharyngeal carcinoma of undifferentiated type. Cancer.;98:288-91

20. .Wei WI, Yuen AP, Ng RW, Kwong DL, Sham JS(2004): Quantitative analysis of plasma cell-free Epstein-Barr virus DNA in nasopharyngeal carcinoma after salvage nasopharyngectomy: a prospective study. Head Neck.;26:878-83.
21. .Thijssen MA, Swinkles DW, Ruers TJ, et al (2002): Difference between free circulating plasma and serum DNA in patients with colorectal cancer metastasis. Anticancer Res.;22:421-5.

22. Kamat AA, Bischoff FZ, Dang D, et al(2006): Circulating cell-free DNA: A novel biomarker for response to therapy in ovarian carcinoma. Cancer Biol Therapy.;5:1369-74.

23. Nawroz H, Koch W, et al(1996): Microsatellite alterations in serum DNA of head and neck cancer patients. Nat Med;2:1035-1037.

24. Ibanez de Caceres I, Battagli C, Esteller M, et al.(2004): Tumor specific BRCA1 and RASSF1A hypermethylation in serum, plasma and peritoneal fluid from ovarian cancer patients. Cancer Res.;64:6476-81. 